\title{
Naprawy gazociągów stalowych za pomocą technologii niemetalicznych
}

\begin{abstract}
W artykule omówiono użycie nowoczesnych materiałów niemetalicznych do naprawy stalowych gazociągów. Opisano zasadę działania systemu naprawczego oraz wady i zalety w porównaniu z konwencjonalnymi metodami. Poruszono problemy związane z oceną techniczną i zaprojektowaniem rozwiązań w przypadku uszkodzeń powstałych wskutek działania korozji oraz uszkodzeń mechanicznych.
\end{abstract}

Słowa kluczowe: naprawy rurociągów, materiały kompozytowe, technologia niemetaliczna, korozja zewnętrzna, uszkodzenia mechaniczne.

\section{Repair of carbon steel natural gas pipelines with non-metallic solutions}

Repairs of natural gas pipelines require innovative approaches to avoid shutdown or interruption in distribution. These conditions create the necessity for solutions which can be applied when the pipe is in service. The method described in this article is, the application of non-metallic composite reinforcing wraps for external corrosion and mechanical damage defects repairs. In the paper theoretical assumptions of repairs using non-metallic systems and methodology of repair design using composite repair and defect assessment standards have been presented.

Key words: pipeline repair, composite material, non-metallic solution, external corrosion, dent, gouge.

\section{Wprowadzenie}

Transport gazu ziemnego niesie za sobą wysokie wymagania związane z niezawodnością sieci przesyłowej, zapewnieniem bezpieczeństwa w transporcie oraz brakiem negatywnego oddziaływania na środowisko naturalne. Najbardziej rozpowszechnioną metodą przesyłu jest wykorzystanie rurociągów, które w porównaniu do tradycyjnych metod przesyłu, takich jak transport morski, drogowy czy kolejowy, wykazują znacznie mniejszą awaryjność. Oddziaływanie środowiska naturalnego może jednak osłabić strukturę rurociągu w wyniku powstania wżerów korozyjnych lub uszkodzeń mechanicznych.

W celu zapewnienia bezpieczeństwa w czasie eksploatacji rurociągu zostały wprowadzone regulacje w postaci dokumentów normatywnych oraz ustaw określających tryb postępowania operatorów gazociągów przesyłowych. Dokumenty te nakazują operatorowi określenie zagrożeń oraz procedur działań zmierzających do zmniejszenia prawdopodobieństwa awarii. Systemy związane z zarządzaniem siecią przesyłową mają na celu przekazywanie i usystematyzowanie informacji o stanie technicznym sieci oraz o najbliższym otoczeniu gazociągu, tzw. strefie ochronnej. Obejmują kontrolę części i zespołów technologicznych, sprawdzanie poprawności ich działania, okresowe przeglądy, konserwację, a także procedury związane z określeniem zadań naprawczych i modernizacyjnych. Po kompleksowej analizie materiałów eksploatacyjnych, wykonaniu badań mających na celu lokalizację nieszczelności, znalezienie ubytków w izolacji oraz po dokonaniu ekspertyzy danych otrzymanych w ciągu roku eksploatacyjnego typowane są elementy do remontu. Metodologia naprawy zostaje dobrana osobno do każdego defektu z uwagi na dużą różnorodność i zakres uszkodzenia. Na ostateczny wybór sposobu naprawy mogą wpłynąć czynniki związane z:

- rodzajem defektu (korozja, pęknięcie, uszkodzenie mechaniczne),

- rozmiarem i kształtem defektu,

- możliwością i opłacalnością czasowego wyłączenia,

- kwalifikacjami i doświadczeniem pracowników, 
- zagrożeniami związanymi z wykonywaniem prac remontowych,

- rodzajem materiału, z jakiego wykonany jest rurociąg,

- charakterystyką metody,

- kosztami wykonania naprawy.

Istnieje wiele sposobów naprawiania istniejących defektów. Klasyczną metodą naprawy jest czasowe wyłączenie rurociągu i wymiana uszkodzonego segmentu na nowy. Rozwiązanie to wiąże się z wysokimi kosztami i czasowym brakiem przepływu medium. Alternatywę dla tej metody stanowi zastosowanie tulei stalowej, która zostaje naspawana na istniejącą rurę w taki sposób, aby zakryć cały istniejący defekt. Jest to metoda czasochłonna, wymaga inspekcji spawów, jednak może zostać użyta nawet w przypadku bardzo wysokich ciśnień i przewidywanych wycieków. Technologią, która zyskuje coraz większą popularność, jest użycie materiałów niemetalicznych w postaci kompozytowych bandaży z włókna szklanego lub węglowego nasączonych żywicą. Metodę tę może wykorzystać, stosując opaski bądź tzw. mokre bandaże utwardzane już po nałożeniu.

\section{Zastosowanie materiałów niemetalicznych do naprawy rurociągów}

Materiały kompozytowe są kombinacją włókien wzmacniających w osnowie z żywicy polimerowej, które mogą wykazywać wytrzymałość w kierunku obwodowym, osiowym lub osiowym i obwodowym. System naprawczy może występować w postaci fabrycznie utwardzonej opaski bądź bandaży utwardzanych już po nałożeniu. Zastosowanie tej technologii umożliwia przedłużenie żywotności rurociągu oraz zabezpieczenie przed powstawaniem nowych ognisk korozji poprzez użycie materiału odpornego na czynniki korodogenne występujące w glebie. W celu optymalnego zaprojektowania naprawy zostały stworzone standardy napraw niemetalicznych skupione wokół zastosowania bandaży kompozytowych: ISO/TS 24817 [4] oraz ASME PCC-2 [3]. Materiały spełniające wytyczne standardów umożliwiają bezpieczne zaprojektowanie naprawy oraz przedłużenie czasu pracy rurociągu bez konieczności zatrzymania przesyłu.

Jednym z istotnych elementów przeprowadzenia naprawy jest konieczność przygotowania powierzchni, która powinna zostać doprowadzona do poziomu normy SA 2.5, bądź SSPC-SP11 - czyszczenie do gołej stali. Tak wysokie wymagania związane z przygotowaniem powierzchni wynikają z konieczności stworzenia odpowiedniego połączenia adhezyjnego pomiędzy rurą a nakładanym materiałem naprawczym oraz usunięcia wszelkich oznak korozji i zapobiegania rozszerzaniu się defektu w przyszłości. Przekrój poprzeczny przykładowej naprawy został przedstawiony na fotografii 1 .

Na zamieszczonej fotografii zostały zaznaczone wszystkie warstwy skutecznej naprawy przy użyciu materiałów kompozytowych na rurze poddanej działaniu korozji zewnętrznej, zaznaczonej jako punkt (1). Wżer został uzupełniony za pomocą wypełniacza epoksydowego (2) z drobinami tytanu

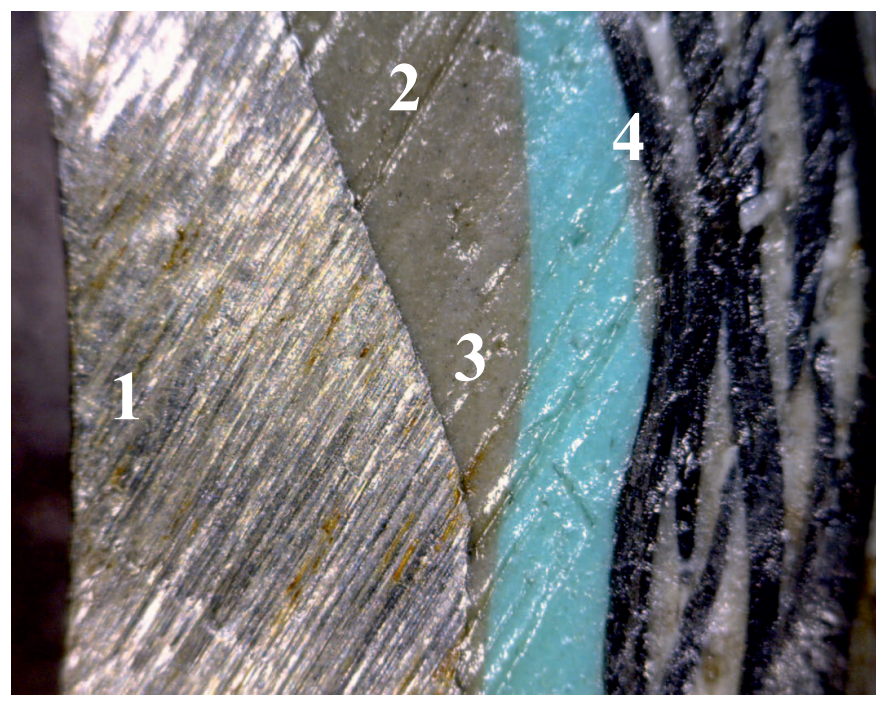

Fot. 1. Przekrój poprzeczny wykonanej naprawy

w celu uniknięcia koncentracji naprężeń w defekcie oraz przeniesienia obciążeń z defektu na bandaż wzmacniający. Wypełnienie powinno przywrócić kształt rurociągu do pierwotnego oraz wygładzić wszystkie nierówności i zagłębienia. Na odpowiednio przygotowaną powierzchnię i utwardzony wypełniacz nałożona została cienka warstwa z podkładu antykorozyjnego (3), który zapewnia również odpowiednie połączenie pomiędzy podłożem a materiałem wzmacniającym. Grubość oraz długość naprawy (4) zostały dobrane zgodnie z obliczeniami inżynierskimi, zapewniającymi przywrócenie zdolności rurociągu do bezpiecznej pracy w warunkach projektowych. Długość owinięcia ma znaczenie w celu uniknięcia koncentracji naprężeń i dla równomiernego ich rozprowadzenia na całej długości bandażu. Tak wykonana naprawa ma zdolność wzmocnienia i zabezpieczenia antykorozyjnego nawet na okres pięćdziesięciu lat.

\section{Naprawa wżerów zewnętrznych przy użyciu materiałów kompozytowych}

Izolacja, którą pokryte są gazociągi, zapewnia ochronę antykorozyjną przed czynnikami zewnętrznymi. Na przestrzeni lat zdolności tych powłok maleją bądź ulegają one zniszczeniu, co często skutkuje powstawaniem obszarów objętych 
wżerami korozyjnymi. Lokalne zmniejszenie grubości ścianki może powodować utratę wytrzymałości gazociągu, powstanie pęknięć lub nawet nieszczelności. Metodą naprawczą, zdobywającą coraz większą popularność, jest użycie bandaży polimerowych, które jednocześnie wzmacniają osłabione obszary i odbudowują izolację.

Przykładową naprawę wżerów korozyjnych na gazociągu przy użyciu materiałów kompozytowych można zrealizować przy wykorzystaniu bandaża z włókna szklanego Syntho-Glass ${ }^{\circledR}$ XT. Badania wykorzystujące technologię ILI wykazały obecność wżerów punktowych. Głębokość defektów według odczytów wynosiła od $20 \%$ do $70 \%$, co wymusiło na operatorze wykonanie prac remontowych na wskazanym odcinku. Rurociąg, o średnicy zewnętrznej $D=20$ cali i grubości ścianki $t=0,375$ cala, został zaprojektowany do transportu gazu ziemnego o ciśnieniu wewnętrznym 60 barów i został wykonany ze stali X52 przy współczynniku projektowym $\mathrm{F}=0,6$. Pierwszym krokiem w celu poprawnego obliczenia długości oraz grubości materiału było sklasyfikowanie wżerów pod względem głębokości anomalii $d$ oraz długości w kierunku osiowym $\mathrm{Lm}$. $\mathrm{Z}$ wykorzystaniem równania z rozdziału 4.2 ASME B31G [2] możliwe było obliczenie bezpiecznego ciśnienia wewnętrznego $P s$, jakie może przenosić rurociąg bez obawy o jego zniszczenie wskutek braku wytrzymałości na wysokie ciśnienie wewnętrzne. Równania i wyniki zostały przedstawione poniżej [4]:

$$
P s=1,1 P \max \left[\frac{1-\frac{2}{3}\left(\frac{d}{t}\right)}{1-\frac{2}{3}\left(\frac{d}{t \sqrt{A^{2}+1}}\right)}\right][\mathrm{MPa}]
$$

gdzie:

$$
\begin{gathered}
A=0,893\left(\frac{L m}{\sqrt{D t}}\right) \\
P \max =\frac{s D}{2 t} \cdot F[\mathrm{MPa}]
\end{gathered}
$$

Wyniki obliczeń zamieszczone w tablicy 1 pokazały, że wartość bezpiecznego ciśnienia nie zależy tylko od głębokości wżeru, ale również od długości defektu. Mały defekt o długości 1 cala powodował nieznaczną zmianę zdolności
Tablica 1. Zależność bezpiecznego ciśnienia wewnętrznego od długości i głębokości wżeru

\begin{tabular}{|c|c|c|c|}
\hline \multirow{2}{*}{ Ubytek ścianki } & \multicolumn{3}{|c|}{ Długość } \\
\cline { 2 - 4 } & $1 \mathrm{cal}$ & 3 cale & 5 cali \\
\hline $40 \%$ & 87,1 & 87,10 & 75,6 \\
\hline $60 \%$ & 85,9 & 74,53 & 67,3 \\
\hline $80 \%$ & 84,0 & 66,90 & 57,4 \\
\hline
\end{tabular}

przesyłowej rurociągu. Pomimo dużej głębokości wżerów dopiero defekt o długości 5 cali wymaga naprawy i strukturalnego wzmocnienia. W przypadku braku spadku zdolności przesyłowych rurociągu poniżej 60 barów zastosowana została minimalna dopuszczona przez testy kwalifikacyjne ilość materiału, która zapewnia odbudowę utraconej geometrii, ochronę antykorozyjną oraz zabezpieczenie przed efektami zmęczeniowymi. W przypadku defektu o długości 5 cali i ubytku $80 \%$ konieczne było zaprojektowanie naprawy, aby przywrócić projektowe właściwości rurociągu. Obliczenia zostały przeprowadzone $\mathrm{z}$ wykorzystaniem równania 3 z rozdziału 3.4.3 ASME PCC-2:2011 [3]:

$$
t_{\text {min }}=\frac{D}{2 s}\left(\frac{E_{s}}{E_{c}}\right)\left(P-P_{s}\right)[\mathrm{mm}]
$$

gdzie:

$s$ - dopuszczalna granica plastyczności materiału, z którego wykonany jest rurociąg $(215,1 \mathrm{MPa})$,

$E_{s}$ - moduł Younga stali (200 GPa),

$E_{c}$ - moduł Younga Syntho-Glass ${ }^{\circledR}$ XT $(24,8 \mathrm{GPa})$,

$P$ - ciśnienie projektowe (6 MPa),

$P_{s}-$ maksymalne bezpieczne ciśnienie $(5,7 \mathrm{MPa})$.

$$
t_{\min }=\frac{D}{2 s}\left(\frac{E_{s}}{E_{c}}\right)\left(P-P_{s}\right)=4,87[\mathrm{~mm}]
$$

Wymagana grubość naprawy materiałem Syntho-Glass ${ }^{\circledR}$ XT wynosi 4,87 mm. Ta grubość zapewnia przywrócenie właściwości projektowych rurociągu oraz przedłużenie jego żywotności. Aplikowanie materiału zostało przeprowadzone przy ciśnieniu zredukowanym do wartości bezpiecznej w celu zmniejszenia naprężeń i odkształceń powstałych w miejscu uszkodzenia rurociągu.

\section{Uszkodzenia mechaniczne}

Defekty powstałe na skutek oddziaływań zewnętrznych, takich jak wgniecenia, wyżłobienia i ugięcia, są jednymi z najbardziej niebezpiecznych uszkodzeń rurociągów. Powodują one ostre zmiany geometrii, które często pomimo braku utraty grubości ścianki mogą prowadzić do zniszczenia instalacji. Koncentracja naprężeń, wraz z eksploatacją, może skutko- wać dalszymi zmianami, powodując pęknięcia, i w końcu prowadzi do utraty integralności. Klasyczną metodą naprawy takich uszkodzeń jest wyłączenie instalacji z pracy i wymiana uszkodzonego elementu rurociągu bądź naspawanie stalowej tulei nad uszkodzeniem. Metoda stalowego rękawa nie zatrzymuje propagacji defektu, jedynie zabezpiecza przed 
wyciekami, tworząc nową część rurociągu o większej średnicy. Użycie materiałów niemetalicznych jest rozwiązaniem, które wprowadza nowe możliwości w naprawie uszkodzeń mechanicznych. Dzięki wypełnieniu całego defektu wypełniaczem oraz nałożeniu bandaża wzmacniającego następuje uniknięcie koncentracji naprężeń na skutek zdolności wypełniacza epoksydowego do przenoszenia obciążeń. Największym jednak wyzwaniem związanym z projektowaniem naprawy jest określenie maksymalnego czasu jej trwałości. Amerykański standard API 579 Fitness-For-Service [1] umożliwia w rozdziale dwunastym ocenę techniczną wgnieceń o głębokości do 7\% średnicy oraz obliczenie liczby cykli bezpiecznej pracy rurociągu. Założenia pokazane w standardzie zostały przedstawione poniżej na przykładzie naprawy wgniecenia z wykorzystaniem materiału Viper-Skin ${ }^{\mathrm{TM}}$. Materiał ten jest bandażem o splocie z włókna węglowego i osnowie z żywicy poliuretanowej. Właściwości mechaniczne materiału są znacznie lepsze niż w przypadku włókien szklanych, moduł Younga wynosi 55,2 GPa. Zastosowanie włókna węglowego wiąże się z mniejszymi możliwościami odkształcenia materiału w czasie pracy, co zabezpiecza przed propagacja defektów w stali. Obliczenie bezpiecznej liczby cykli $N_{c}$ zostało przedstawione w równaniu poniżej:

$$
N_{c}=562,2\left[\frac{\sigma_{u t s}}{2 \sigma_{A} K_{d} K_{g}}\right]^{5,26}
$$

gdzie:

$$
\begin{gathered}
\sigma_{A}=\sigma_{a}\left[1-\left(\frac{\sigma_{m, \max }^{c}-\sigma_{a}}{\sigma_{u t s}}\right)^{2}\right]^{-1} \\
\sigma_{a}=\frac{\sigma_{m, \max }^{c}-\sigma_{m, \min }^{c}}{2}[\mathrm{MPa}]
\end{gathered}
$$

gdzie:

$C_{s}$ - współczynnik zmęczeniowy opisujący wgniecenia,

$C_{u l}$ - współczynnik zmiany jednostki,

$d_{d p}-$ głębokość defektu w czasie eksploatacji [in],

$d_{d 0}-$ głębokość wgniecenia przy wyłączonym przesyle [in],

$D$ - średnica zewnętrzna [in],

$K_{d}$ - wskaźnik koncentracji naprężeń używany w przypadku wgnieceń,

$K_{g}$ - wskaźnik koncentracji naprężeń używany w przypadku wyżłobień,

$M A W P$ - maksymalne ciśnienie robocze [MPa],

$N_{c}$ - dopuszczalna liczba cykli pracy,

$P_{\max }-$ maksymalne ciśnienie w czasie cyklu pracy [MPa],

$P_{\text {min }}-$ minimalne ciśnienie w czasie cyklu pracy [MPa],

$R_{d}$ - promień u podstawy wgniecenia [in],

$\sigma_{a}$ - amplituda naprężeń obwodowych [MPa],

$\sigma_{A}$ - cykliczne naprężenie obwodowe [MPa],
$\sigma_{m}^{C}$ - naprężenia obwodowe [MPa],

$\sigma_{m, \max }^{C}$ - naprężenia obwodowe związane z maksymalnym ciśnieniem [MPa],

$\sigma_{m, \min }^{C}$ - naprężenia obwodowe związane z minimalnym ciśnieniem $[\mathrm{MPa}]$,

$\sigma_{u t s}-$ wytrzymałość na rozciąganie [MPa],

$t_{c}$ - przewidywana grubość ścianki w końcowym etapie eksploatacji [in].

Tablica. 2. Wartości projektowe

\begin{tabular}{|l|c|c|}
\hline \multicolumn{3}{|c|}{ Dane projektowe } \\
\hline \multicolumn{3}{|c|}{ Naprawa wgnieceń } \\
\hline Średnica & 12,750 & in \\
\hline Nominalna grubość ścianki, $t_{\text {nom }}$ & 0,188 & in \\
\hline $\begin{array}{l}\text { Głębokość wgniecenia } \\
\text { w czasie pracy, } d_{d p}\end{array}$ & 0,490 & in \\
\hline Głębokość wgniecenia, $d_{d 0}$ & 0,700 & in \\
\hline Promień wgniecenia, $r_{d}$ & 2,000 & in \\
\hline$\sigma_{u t s}$ & 413,7 & $\mathrm{MPa}$ \\
\hline \multicolumn{2}{|c|}{ Składowe cyklu ciśnieniowego } \\
\hline$P_{\max }$ & 6,1 & $\mathrm{MPa}$ \\
\hline$P_{\min }$ & 0,7 & $\mathrm{MPa}$ \\
\hline$\sigma_{m, \max }^{C}$ & 208 & $\mathrm{MPa}$ \\
\hline$\sigma_{m, \min }^{C}$ & 23,3 & $\mathrm{MPa}$ \\
\hline$\sigma_{a}$ & 92,3 & $\mathrm{MPa}$ \\
\hline$\sigma_{A}$ & 96,6 & $\mathrm{MPa}$ \\
\hline$K_{d}$ & 2,05 & \\
\hline$C_{u l}$ & 25,40 & \\
\hline$C_{s}$ & 1 & \\
\hline$K_{g}$ & $3200 \div 363$ & \\
\hline Dopuszczalna liczba cykli, $N_{c}$ & \\
\hline & 1,00 & \\
\hline & & \\
\hline
\end{tabular}

W celu wprowadzenia zależności liczby dopuszczalnych cykli pracy od naprawy kompozytowej zostały wyprowadzone równania określające maksymalne dopuszczalne naprężenia obwodowe w funkcji grubości naprawy.

$$
\sigma_{m, \max }^{c}=E \varepsilon_{m, \max }^{c}
$$

gdzie:

$$
\varepsilon_{m, \text { max }}^{c}=\frac{P_{\text {max }} \cdot D}{2 \cdot\left(E_{c} \cdot t_{\text {repair }}+E_{s} \cdot t_{s}\right)}
$$

oraz

$$
\sigma_{m, \min }^{c}=E \varepsilon_{m, \min }^{c}
$$

gdzie:

$$
\varepsilon_{m, \text { min }}^{c}=\frac{P_{\text {min }} \cdot D}{2 \cdot\left(E_{c} \cdot t_{\text {repair }}+E_{s} \cdot t_{s}\right)}
$$


Wyniki ukazujące liczbę dopuszczalnych cykli pracy w zależności od grubości nałożonego materiału Viper-Skin ${ }^{\mathrm{TM}}$ zostały zaprezentowane na rysunku 1 .

Obliczenia i przedstawione rezultaty pokazują znaczną poprawę wytrzymałości zmęczeniowej wraz ze wzrostem grubości nałożonego materiału naprawczego. Kolorem niebieskim zaznaczono minimalny wzrost liczby cykli, a kolorem czerwonym - maksymalny. Rozbieżność pomiędzy wynikami wiąże się $\mathrm{z}$ dużą różnicą pomiędzy ciśnieniem maksymalnym i minimalnym, które decydują o naprężeniach powstałych w rurociągu. Użycie technologii napraw niemetalicznych znacząco wpływa na żywotność uszkodzonej struktury oraz na bezpieczeństwo jej użytkowania. Zachowanie bandaża kompozytowego pod wpływem obciążeń cyklicznych znacznie różni się od zachowania stali $\mathrm{z}$ uwagi na powolną propagację defektu. Konstrukcje stalowe pod wpływem długotrwałych zmiennych obciążeń tracą

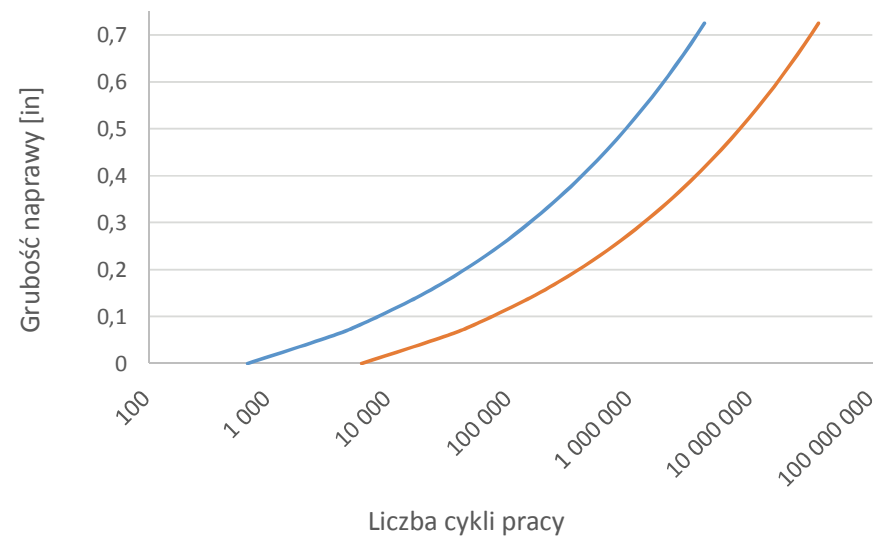

Rys. 1. Zależności liczby cykli pracy od grubości naprawy

na wytrzymałości oraz gwałtownie pękają, co grozi poważnymi następstwami. Uszkodzenia materiałów polimerowych następują w sposób powolny, poprzez stopniową utratę własności.

\section{Podsumowanie}

Materiały kompozytowe otwierają nowe możliwości w pracach remontowych prowadzonych na rurociągach stalowych. Ich użycie nie wiąże się już jedynie z naprawami tymczasowymi, ale również z trwałym usunięciem uszkodzeń. Niewątpliwą zaletę stanowi możliwość prowadzenia prac $\mathrm{w}$ trakcie eksploatacji, bez konieczności spawania oraz w warunkach niewymagających skomplikowanej aparatury. Jest to jednak materiał o ukierunkowanych właściwościach mechanicznych, w przeciwieństwie do izotropowej stali. Jego aplikowanie wiąże się z konkretnymi zadaniami, jakie musi spełnić materiał naprawczy, aby w pełni wykorzystać jego potencjał oraz odpowiednio zabezpieczyć uszkodzony obszar. Zwiększające się możliwości zastosowania oraz rozwój metod projektowych pozwalają na skuteczne i bezpieczne wykorzystanie omawianej technologii w różnych rodzajach uszkodzeń. Jest to alternatywa dla użycia tradycyjnych metod stalowych, które przez lata wykazywały dużą skuteczność. Zastosowanie materiałów polimerowych nie ogranicza się jedynie do napraw zewnętrznych wżerów korozyjnych i uszkodzeń mechanicznych, lecz pozwala także wzmocnić pęknięcia, a nawet zwiększyć możliwości przesyłowe rurociągu, przy zachowanych warunkach bezpieczeństwa. Prace nad rozwojem technologii sprawiają, że materiały stają się coraz wytrzymalsze, odporne na działanie czynników zewnętrznych, a ich użycie może być projektowane na coraz dłuższe okresy, sięgające już kilkudziesięciu lat.

Prosimy cytować jako: Nafta-Gaz 2016, nr 8, s. 632-637, DOI: 10.18668/NG.2016.08.07

Artykuł nadesłano do Redakcji 1.02.2016 r. Zatwierdzono do druku 29.04.2016 r.

Artykuł powstał na podstawie referatu zaprezentowanego na Konferencji Naukowo-Technicznej FORGAZ 2016 „Techniki i technologie dla gazownictwa - pomiary, badania, eksploatacja”, zorganizowanej przez INiG - PIB w dniach 13-15 stycznia 2016 r. w Muszynie.

\section{Akty prawne i normatywne}

[1] ASME API 579 Fitness-For-Service 2007.

[2] ASME B31G Manual for Determining the Remaining Strength of Corroded Pipelines.

[3] ASME PCC-2:2011 Repair of Pressure Equipment and Pipinig.

[4] ISO/TS 24817:2006 Petroleum, petrochemical and natural gas industries - Composite repairs for pipework - Qualification and design, installation, testing and inspection.

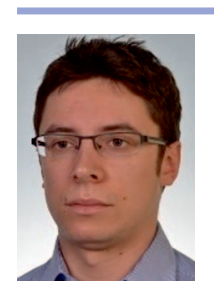

Inż. Grzegorz MAJOR

Inżynier mechanik

NRI EurAsia Ltd.

ul. Cieszyńska 434/3

43-382 Bielsko-Biała

E-mail: GMajor@NeptuneResearch.com 